\title{
Hyperprolactinemia Due to the Sulpiride Addition to Venlafaxine Treatment: A Case Report
}

\author{
Venlafaksin Tedavisine Sülpirid Eklenmesi Sonrası Görülen Hiperprolaktinemi: Olgu Sunumu
}

\author{
İbrahim Yağcl', Yasin Tașdelen², Yüksel Kıvrak ${ }^{3}$ \\ ${ }^{1}$ Department of Psychiatry, Kars Harakani State Hospital, Kars; ${ }^{2}$ Department of Psychiatry, Edremit State Hospital, Balikesir; \\ ${ }^{3}$ Department of Psychiatry, Kafkas University, Kars, Turkey
}

\begin{abstract}
Hyperprolactinemia, is the most common hypothalamo-hypopysial endocrine disorder. The most common etiologies are; hypophysis adenoma, chronic kidney failure and antiphyschotic drug use. Normal range of prolactin blood level is below 20-25 ng/ml. Antipsychotic drugs cause hyperprolactinemia by blocking the D2 dopamine receptors in the frontal lobe of the hypophysis. The most common symptoms of hyperprolactinemia due to antipsychotic drug use are: galactorrhea, menstrual cycle dysregulation, amenorrhea, decrease in libido, breast sensitivity, decrease in the bone mineral density. Therefore, it is important to diagnose galactorrhea as early as possible. As far as we know there is no reported cases of hyperprolactinemia induced galactorrhea due to very low dose (50 mg/day) sulpiride use. In this study, we report a case of galactorrhea due to hyperprolactinemia as a result of sulpiride $50 \mathrm{mg} /$ daily drug addition to the venflaxine $150 \mathrm{mg} /$ daily treatment in a depressive patient.
\end{abstract}

Key words: sulpiride; hyperprolactinemia; antipsychotic drugs; depression

\section{ÖZET}

Hiperprolaktinemi, hipotalamo-hipofizyal eksenin en çok karșılașllan endokrin bozukluğudur. En sık nedenleri hipofiz adenomları, kronik böbrek yetersizliği ve antipsikotik ilaç kullanımıdır. Prolaktinin normal düzeyi 20-25 ng/ml altındadır. Antipsikotik ilaçlar hiperprolaktinemiye ön hipofizdeki D2 dopamin reseptörlerini bloke ederek neden olurlar. Antipsikotiklerin neden olduğu hiperprolaktineminin en sık belirtileri; galaktore, menstrüel döngü düzensizlikleri, amenore, libidoda azalma, gögüste duyarlılık, kemik mineral dansitesinde azalmadır. Bu nedenle de galaktoreyi erken fark etmek önemlidir. Bilebildiğimiz kadarı ile literatürde sülpiridin çok düșük dozda (50 mg/gün) kullanımı sonrası görülen hiperprolaktinemiye bağlı galaktore olgusu bulunmamaktadır. Bu yazıda depresyon tanısı ile venlafaksin 150 mg/gün kullanan hastanın tedavisine sülpirid 50 mg/gün eklenilmesi sonucu hiperprolaktinemiye bağlı galaktore görülen bir olgu sunulmuștur.

Anahtar kelimeler: sülpirid; hiperprolaktinemi; antipsikotik ilaçlar; depresyon

Yüksel Kıvrak, Kafkas Üniversitesi Tip Fakültesi Psikiyatri Anabilim Dalı, Paşaçayır Mah., Kars, Türkiye 36000 Kars - Türkiye, Tel. 04742251150 Email.ykivrak21@gmail.com

Gelis Taribi: 07.04.2017 • Kabul Tarihi: 21.12.2017

\section{Introduction}

Hyperprolactinemia, is the most common hypothalamo-hypophysial endocrine disorder of the hypothalamo-hypophysial axis ${ }^{1}$. In this disorder, plasma prolactin level is higher than $18 \mathrm{ng} / \mathrm{ml}$ and $30 \mathrm{ng} / \mathrm{ml}$ in men and women, respectively ${ }^{2}$. The most common causes are pituitary adenomas, chronic renal failure, and the use of antipsychotic drugs. Antipsychotic drugs block D2 dopamine receptors in the frontal lobe of the hypophysis and therefore cause hyperprolactinemia ${ }^{3}$. Most common symptoms of the antipsychotic drug induced hyperprolactinemia are: galactorrhea, menstrual dysregulation, amenorrhea, decrease of libido, breast sensitivity and reduction of the bone mineral density ${ }^{4}$. Early diagnosis and treatment of galactorrhea is important since it can effect the patient both physically and emotionally.

Sulpiride is a second generation antipsychotic drug. Such as the other first and second generation antipsychotic drugs, sulpiride is commonly used in both psychotic and non-psychotic disorders by clinicians. We report a patient who complained of galactorrhea due to hyperprolactinemia, after she was prescribed 50 $\mathrm{mg}$ /day sulpiride in addition to her current depression treatment with $150 \mathrm{mg} /$ day venlafaxine.

\section{Case}

Our case was a 36 year old married housewife who had two children. Her education background was high school graduation. She had been treated for depression for four years and had used various antidepressant drugs. In the initial physical examination, she was noted to have mild self-care loss and her appearance was in accordance with her age. Her intelligence level was normal and she did not have any perception-memory 
disorders. Her emotional status was dysphoric, there was a decrease in her libido, her sleep condition and her affectivity were normal. In her family history no psychiatric disorder history was present. She did not have alcohol or drug use, operation and chronic disorder history. Her menstrual cycle was regular, there was no pregnancy suspicion or any related drug use. Althrough her current treatment with venlafaxine $150 \mathrm{mg}$ /day, had lessened her depressive symptoms, she was complaining of headache and migratory pain. Therefore sulpiride $50 \mathrm{mg} /$ day was prescribed in addition to her current treatment. In the follow-up examination that was one month later, her previous complaints were partially recovered but she complained of abnormal breast milk from both breasts and breast pain. Hyperprolactinemia induced galactorrhea due to antipsychotic drug use was thought to be the possible etiology. In order to exclude other possible organic etiologies, the patient was consulted by the neurology, endocrinology, gynaecology and obstetrics departments. Plazma blood prolactin level was measured as $91.39 \mathrm{ng} / \mathrm{ml}$. She had been using various antidepressant drugs for the last 4 years and she had never experienced these complaints before. No additional patologies were detected in the other tests (plazma TSH, T3, T4, ALT, AST, urea, creatinine, glucose levels, hemogram, cranial MRI, hypophysis MRI) and examinations performed. Sulpiride was discontinued since it was considered as the possible etiology. In the next follow-up examination that was one month later her pain symptom had recovered and plazma prolactin level was found to have decreased to $17.94 \mathrm{ng} / \mathrm{ml}$.

\section{Discussion}

Prolactin is a polypeptide hormone which is secreted in a circadian rthym by the lactotroph cells in the frontal lobe of the hypophysis ${ }^{4}$. In drug induced galactorrhea cases, plasma prolactin level is normal or below $100 \mathrm{ng} /$ $\mathrm{ml}^{5}$. In our case plasma prolactin level was $91.39 \mathrm{ng} / \mathrm{ml}$ and in accordance with the literature. In the first few minutes following the intramuscular injections prolactin level usually increases ${ }^{6}$. Following the oral drug use, plasma prolactin level usually increases gradually in a week and remains constant afterwards ${ }^{7}$. Usually after 48-96 hours after discontinuing the oral antipsychotic drug, plasma prolactin level decreases back to its normal value $^{8}$. When hyperprolactinemia is detected, treatment options are to decrease the antipsychotic drug dosage, to change the current antipsychotic drug with another one that does not effect prolactin level or to add a partial dopamine antagonist to the current treatment.
Naranjo's drug adverse reaction probability scale is used to assess adverse drug reactions. According to this scale, if the score is 9 and higher the reaction is considered to be definite, if the score is 5 to 8 it is probable, if the score is 1 to 4 it is possible and if the score is 0 or less it is doubtful'. When this scale was applied to our case, total score was found to be 7 points with the presence of former literature reports about hyperprolactinemia due to sulpiride use ( 1 point), the initiation of hyperprolactinemia being after the suspected drug's use ( 2 points), decrease of plasma prolactin level after the discontinuation of the drug ( 1 point), there being no other possible causes for the hyperprolactinemia $(2$ points) and the adverse event's being confirmed by an objective evidence ( 1 point). This finding suggest that the probable cause of the hyperprolactinemia was the use of sulpiride.

Plasma prolactin level increase is frequently reported due to sulpiride use. While in low doses it acts as a partial dopamine agonist, in high doses it acts like a typical D2 antagonist. Althrough in antipsychotic treatment doses, sulpiride can cause EPS and plasma prolactin level increase, in low doses it can be useful for both activating the patient and aiding the depression treatment, since sulpiride tends to bind to D3 in low doses ${ }^{10}$. Its use in patients with depressive disorders and somatic complaints can also be useful for treating complaints like widespread pain and headache ${ }^{11}$. As far as we know there is no reported cases of hyperprolactinemia induced galactorrhea due to very low dose ( $50 \mathrm{mg} /$ day) sulpiride use. Due to the adverse effects of the antipsychotic drugs, the patient's life quality might decrease as a result of the negative effects of the drug on patient's social and sexual functions. Consistency of the treatment is worsened because of these adverse effects. When prescribing sulpiride, clinicians should keep in mind the possibilitu of galactorrhea development even in very low doses and especially in the high risk group. Clinicians should also question galactorrhea symptoms in the follow-up examinations. This might be useful for building better patient-clinician relationship.

\section{References}

1. Kinon BJ, GilmoreJA, Liu H,Halbreich UM. Hyperprolactinemia in response to antipsychotic drugs: characterization across comparative clinical trials. Psychoneuroendocrinol 2003;28(2):69-82. 
2. Wieck, A, Haddad P. Hyperprolactinaemia caused by antipsychotic drugs. BMJ 2002;324:250-2.

3. Green AI, Brown WA. Prolactin and neuroleptic drugs. Endocrinol Metab Clin North Am 1988;17(1):213-23.

4. Torre D, Falorni A, Pharmacological causes of hyperprolactinemia. Ther Clin Risk Manag 2007;3:929-51.

5. Edge DS, Segatore M. Assessment and management of galactorrhea. Nurse Pract 1993;18(6):35-49.

6. Langer G, Sachar EJ, Halpern FS. The prolactin response to neuroleptic drugs. A test of dopaminergic blockade: neuroendocrine. J Clin Endocrinol Metab 1977;45:996-1002.

7. Spitzer M, Siajjad R, Benjamin F. Pattern of development of hyperprolactinemia after initiation of haloperidol therapy. Obstet Gynecol 1998;91:693-5.
8. Haddad PM, WieckA.Antipsychotic-induced hyperprolactinemia. Drugs 2004;64:2291-314.

9. Naranjo CA, Busto U, Sellers EM, Sandor P, Ruiz I, Roberts EA et al. "A method for estimating the probability of adverse drug reactions" Clin Pharmac Ther 1981;30(2):239-45.

10. Stahl SM(2012)Stahl'ın Temel Psikofarmakolojisi. (Çev. Ed. İT Uzbay). İstanbul Tip Kitabevi, İstanbul, 2012.

11. Rouillon F, Rahola G, Van Moffaert M. Sulpiride in the treatment of somatoform disorders: results of a European observational study to characterize the responder profile. J Int Med Res 2001;29:304-13. 